\title{
Big data in pharmacy practice: current use, challenges, and the future [Corrigendum]
}

Ma C, Smith H, Chu C, Juarez D. Integr Pharm Res Pract. 2015;4:91-99.

Page 96, left-hand column, the reference citations for the following text "The US Hawaii Health Information Exchange (HHIE) is a 501 (C) (3) nonprofit, state-wide organization established in 2006. By facilitating assessment and implementing targeted health initiatives, HHIE strives to enhance care coordination, to improve the health outcomes of Hawai' i's patients, and to reduce the cost of care for both patients and health care providers. ${ }^{39}$ " and "A project called Pharm2Pharm, funded for $\$ 14.3$ million USD by an innovation grant from CMS, uses information provided by HHIE to facilitate all written communication between hospitals and outpatient health care teams. ${ }^{40}$ " were incorrect. The citation numbers 39 and 40 in this section should be replaced by number 55 .
Page 96, left-hand column, the reference citations for the following text "HHIE Community Health Record, a tool that pharmacists can use to access patient lab values and other clinical information. This complete record of medications, labs, and other clinical information can then be utilized to support additional health care strategies specifically designed for each patient. ${ }^{39,40}$ " were incorrect. The citation numbers 39 and 40 in this section should be replaced by number 55 .

Page 99, the following reference should be added to the reference list as reference number 55 "Pellegrin KL. The Daniel K. Inouye College of Pharmacy Scripts: Pharm2Pharm: Leveraging Medication Expertise Across the Continuum of Care. Hawaii J Med Public Health. 2015;74(7):248-252."
Integrated Pharmacy Research and Practice

\section{Publish your work in this journal}

Integrated Pharmacy Research and Practice is an international, peer-reviewed, open access, online journal, publishing original research, reports, reviews and commentaries on all areas of academic and professional pharmacy practice. This journal aims to represent the academic output of pharmacists and pharmacy practice with particular focus on integrated care. All papers are carefully

\section{Dovepress}

peer reviewed to ensure the highest standards as well as ensuring that we are informing and stimulating pharmaceutical professionals. The manuscript management system is completely online and includes a very quick and fair peer-review system, which is all easy to use. Visit http://www.dovepress.com/ testimonials.php to read real quotes from published authors. 